University of Nebraska - Lincoln

DigitalCommons@University of Nebraska - Lincoln

Entomology Papers from Other Sources

Entomology Collections, Miscellaneous

1999

\title{
Male crucifer flea beetles produce an aggregation pheromone
}

Chengwang Peng

North Dakota State University

Robert J. Bartelt

USDA-ARS

Michael J. Weiss

North Dakota State University

Follow this and additional works at: https://digitalcommons.unl.edu/entomologyother

Part of the Entomology Commons

Peng, Chengwang; Bartelt, Robert J.; and Weiss, Michael J., "Male crucifer flea beetles produce an aggregation pheromone" (1999). Entomology Papers from Other Sources. 4.

https://digitalcommons.unl.edu/entomologyother/4

This Article is brought to you for free and open access by the Entomology Collections, Miscellaneous at DigitalCommons@University of Nebraska - Lincoln. It has been accepted for inclusion in Entomology Papers from Other Sources by an authorized administrator of DigitalCommons@University of Nebraska - Lincoln. 


\title{
Male crucifer flea beetles produce an aggregation pheromone
}

\author{
CHENGWANG PENG, ROBERT J. BARTELT* and MICHAEL J. WEISS \\ Department of Entomology, North Dakota State University, Fargo, North Dakota, and *USDA-ARS, Northern Regional Research \\ Center, Peoria, Illinois, U.S.A.
}

Key words. Aggregation pheromone, crucifer, Phyllotreta cruciferae.

\section{Introduction}

The flea beetle, Phyllotreta cruciferae (Goeze), is a pest of crucifer crops throughout most of North America (Lamb, 1989). Adult beetle feeding on crucifer vegetables causes small pits in the epidermis, which affects the marketability (Vaughn \& Hoy, 1993). Larger population of beetles can kill or stunt seedlings. In the northern Great Plains of the United States and Canada, this species is the most serious pest of springplanted oilseed rape, Brassica napus and B. rapa (Lamb, 1989; Weiss et al., 1991). Overwintering adults feed on the cotyledons and stems, resulting in seedling mortality and causing the crop to mature unevenly when the population is high (Burgess, 1977; Lamb, 1989).

Peng \& Weiss (1992) first reported evidence that $P$. cruciferae produces an aggregation pheromone. In subsequent studies which attempted to isolate and identify the pheromone, it was proposed first to determine whether one sex of beetles produces pheromones, and if so, then to bioassay and identify the sex-specific compounds. Sex-specific compounds are often pheromone candidates (Bartelt et al., 1990a; Pierce et al., 1995). Here, the results of field-trapping experiments to determine whether males or females produce the pheromone are presented.

\section{Methods}

Field-trapping experiments were conducted at Carrington, North Dakota, in September 1995 and at Minot, North Dakota, in June 1996. The traps used in these studies were designed after Peng \& Weiss (1992). Oilseed rape (B. napus cv. 'Westar') were grown in 12-cm plastic pots using Sunshine Mix \#3 as a potting medium, about fifty seedlings per pot, in the glasshouse until they were placed outdoors 5 days after emergence. Plants

Correspondence: Dr M. J. Weiss, Department of Entomology, North Dakota State University, Fargo, North Dakota 58105, U.S.A.

E-mail: pseshead@uidaho.edu in the glasshouse were watered as needed and fertilized the fourth day after emergence. Pots were covered with a fine mesh organdy just before they were placed in the field so that volatile chemicals readily passed through the mesh, but field flea beetles were excluded. To test the activity of beetle-derived volatiles, flea beetles were released into pots before tests.

Flea beetles used in the 1995 trial were collected from oilseed rape in late August at Carrington, North Dakota. Flea beetles used in 1996 trials were collected from field pennycress (Thalaspi arvense) in late May at Fargo, North Dakota. They were maintained in the glasshouse on oilseed rape seedlings in vented cages at about $23 \pm 5^{\circ} \mathrm{C}$ and a photocycle of LD 16:8 h. Flea beetles were sexed based on characters at the tip of the abdomen by placing them in a small glass tube ( $2 \mathrm{~mm}$ i.d.) one beetle at a time and examining these characters under a dissecting microscope. In both lateral and ventral view, the abdomen tip is acute in the female and rounded in the male.

Two different techniques were used to capture the flea beetles that were flying toward pots. In 1995, pots were buried halfway in the ground. Pherocon ${ }^{\circledR}$ sticky cards were stapled on wooden stakes and placed vertically about $0.2 \mathrm{~m}$ away from pots to catch flea beetles. In 1996, each pot was placed on a wooden block in the centre of a circular white plastic tray of $30 \mathrm{~cm}$ diameter and $8 \mathrm{~cm}$ deep (Duraco Products, Inc., Streamwood, Illinois). Each tray was filled with soapy water to collect flea beetles (Peng \& Weiss, 1992).

Four field-trapping trials were conducted, one in 1995 and three in 1996. Each treatment consisted of two replicates in 1995 and three replicates in 1996 in each trial, arranged in a randomized complete block design. The distance between pots within a replicate was about $1.5 \mathrm{~m}$ and about $10 \mathrm{~m}$ or more between replicates. In 1995, traps were positioned about $3 \mathrm{~m}$ away from the edge of a oilseed rape field $(\approx 1$ acre in size $)$ in which most plants had died. Two treatments and a control were used: oilseed rape plus forty male beetles, oilseed rape plus forty female beetles, and oilseed rape only (control). Trials in 1996 were conducted in an area with pennycress. Trials I and II consisted of the same treatments: oilseed rape plus twenty male beetles, oilseed rape plus twenty female beetles, 
Table 1. Mean numbers ( \pm SD) of adult flea beetles caught per trap by treatments at Minot in North Dakota in 1996.

\begin{tabular}{llcl}
\hline Treatments & Replicates & Mean numbers of beetles \\
\hline Trial I: June 7-8 & & & \\
20 males + oilseed rape & 3 & $9.0 \pm 4.36$ & $\mathrm{a}$ \\
20 females + oilseed rape & 3 & $0.3 \pm 0.58$ & $\mathrm{~b}$ \\
2 males + oilseed rape & 3 & $1.3 \pm 1.15$ & $\mathrm{~b}$ \\
Oilseed rape only (control) & 3 & $1.0 \pm 0.00$ & $\mathrm{~b}$ \\
& $F=6.79$ & $P=0.018$ & \\
Trial II: June 8-10 & & & \\
20 males + oilseed rape & 3 & $24.0 \pm 11.53$ & $\mathrm{a}$ \\
20 females + oilseed rape & 3 & $7.0 \pm 4.00$ & $\mathrm{~b}$ \\
2 males + oilseed rape & 3 & $9.7 \pm 4.16$ & $\mathrm{~b}$ \\
Oilseed rape only (control) & 3 & $6.7 \pm 3.51$ & $\mathrm{~b}$ \\
& $F=9.09$ & $P=0.009$ & \\
Trial III: June 10-11 & & & \\
20 males + oilseed rape & 3 & $8.7 \pm 3.79$ & $\mathrm{a}$ \\
20 males + 20 females + & 3 & $13.3 \pm 5.13$ & $\mathrm{a}$ \\
$\quad$ oilseed rape & & & \\
& $F=31.90$ & $P=0.030$ & \\
\hline
\end{tabular}

Means followed by a common letter within columns of each trial are not significantly different (Tukey's studentized range test, $\alpha=0.05$ ).

oilseed rape plus two male beetles, and oilseed rape only (control) (Table 1). The treatment of oilseed rape plus two beetles was included to test the minimal number of beetles required to elicit beetle response in the field. The third trial consisted of two treatments and a control: twenty male beetles plus oilseed rape, oilseed rape with twenty males and females each, and oilseed rape only as a control.

Data from 1996 were analysed by analysis of variance (ANOVA) and Tukey's studentized range test at the 5\% level of significance (SAS Institute, 1990). Data from 1995 were not analysed statistically due to the minimal replicates.

\section{Results and Discussion}

In a 1995 preliminary trial, an average of 14.5 beetles was collected after flying to pots containing oilseed rape and males. Only 1.5 and 2.0 beetles were caught in pots with oilseed rape only and oilseed rape plus females, respectively. Thus, there was evidence of a male-produced pheromone.

In subsequent studies in 1996, the present authors found significant differences in numbers of flea beetles caught by treatments in all trials (Table 1). In Trials I and II, only pots containing oilseed rape plus twenty males were significantly attractive to $P$. cruciferae among all treatments. Pots with oilseed rape and two males were not attractive, indicating that more than two males were required for attraction under field conditions. In Trial III, the treatment of oilseed rape with both males and females attracted significantly more beetles than oilseed rape with males only (Table 1). The increased attraction caused by the addition of females to pots could be due to a compound(s) produced by females, but this remains to be investigated.

Two years of studies indicated that male $P$. cruciferae produce aggregation pheromone. The result may help to develop a simpler procedure to identify the flea beetle aggregation pheromone by concentrating on the male-specific compounds. This technique has been successful in several species including a group of nitidulid beetles (Bartelt et al., 1990b). Synthetic pheromone could be used to monitor flea beetle population and to control this important species in combination with insecticides.

\section{Acknowledgement}

This research was supported in part by the USDA, Cooperative State Research Service, under North Central Canola Region Research and Outreach Program.

\section{References}

Bartelt, R.J., Dowd, P.F., Plattner, R.D. \& Weisleder, D. (1990a) Aggregation pheromone of driedfruit beetle, Carpophilus hemipterus. Wind-tunnel bioassay and identification of two novel tetraene hydrocarbons. Journal of Chemical Ecology, 16, 1015-1039.

Bartelt, R.J., Dowd, P.F., Shorey, H.H. \& Weisleder, D. (1990b) Aggregation pheromone of Carpaphilus freemani (Coleoptera: Nitidulidae): a blend of conjugated triene and tetraene hydrocarbons. Chemoecology, 1, 105-113.

Burgess, L. (1977) Flea beetles (Coleoptera: Chrysomelidae) attacking rape crops in the Canadian prairie provinces. The Canadian Entomologist, 109, 21-32.

Lamb, R.J. (1989) Entomology of oilseed Brassica crops. Annual Review of Entomology, 34, 211-229.

Peng, C. \& Weiss, M.J. (1992) Evidence of an aggregation pheromone in the flea beetle, Phyllotreta cruciferae (Goeze) (Coleoptera: Chrysomelidae). Journal of Chemical Ecology, 18, 875-884.

Pierce, H.D., Jr, Groot, P.D., Borden, J.H., Ramaswamy, S. \& Oehlschlager, A.C. (1995) Pheromones on red pine cone beetle, Conophthorus resinosae Hopkins, and its synonym, C. banksianae McPherson (Coleoptera: Scolytidae). Journal of Chemical Ecology, 21, 169-185.

SAS Institute (1990) SAS User's Guide: Statistics. Cary, NC.

Vaughn, T.T. \& Hoy, C.W. (1993) Effects of leaf age, injury, morphology, and cultivars on feeding behaviors of Phyllotreta cruciferae (Coleoptera: Chrysomelidae). Environmental Entomology, 22, 418-424.

Weiss, M.J., McLeod, P., Schatz, B.G. \& Hanson, B.K. (1991) Potential for insecticidal management of flea beetles (Coleoptera: Chrysomelidae) on canola. Journal of Economic Entomology, 84, 1597-1603.

Accepted 17 June 1998 